\title{
Nesting biology and immature stages of the oil-collecting bee Epicharis dejeanii (Apidae: Centridini)
}

\author{
Enderlei Dec, Felipe Vivallo \\ HYMN Laboratório de Hymenoptera, Departamento de Entomologia, Museu Nacional - Universidade Federal do Rio de \\ Janeiro, Quinta da Boa Vista-São Cristóvão, Rio de Janeiro, RJ 20940-040, Brazil
}

Received 22 October 2018 - Revised 28 May 2019 - Accepted 2 July 2019

\begin{abstract}
An aggregation of the oil-collecting bee Epicharis dejeanii Lepeletier was studied at Ilha das Flores, southern Brazil. Data on seasonality, types of floral resources collected, and nesting biology were registered. The nesting area occupied $120 \mathrm{~m}^{2}$ with density of up to $8 \mathrm{nests} / \mathrm{m}^{2}$. The tunnel entrances remained always open and surrounded by a tumulus. Adult activity lasted approximately 70 days. The females built the nest, provisioned food, and layed the egg in 4 days. The nest's architecture was very diverse, and they were between 40 and $140 \mathrm{~cm}$ in depth with one or two brood cells at the end of the tunnel. Diapause occurred in the postdefecating larval stage, and there was no cocoon. Immature stages and nest architecture are described and illustrated.
\end{abstract}

\section{Solitary bee / Larval development / Nesting architecture / Baía da Babitonga}

\section{INTRODUCTION}

The Centridini tribe (Hymenoptera: Apidae) is the largest group of noncorbiculate bees of the Neotropical Region (Michener 2007). In this select group of oil-collecting bees, females of this lineage collect this resource from several botanical families (Vogel 1976) to use it, along with other elements, to construct the brood cells and as food for their progeny (Neff and Simpson 1981; Buchmann 1987).

The nesting habits in centridine bees are diverse. However, the substrate used for many of the species of Centris Fabricius and Epicharis Klug, both genera that conform the tribe, yet is unknown. According to the data available, all species already

Corresponding author: E. Dec, enderlei@hotmail.com Manuscript editor: Yves Le Conte studied of Epicharis construct their nest in soil (Gaglianone 2002).

In general terms, Epicharis species are widely distributed in the Amazon basin with only a few species occurring in other areas on the Neotropics. Despite their wide distribution range, there are only available data on the bionomy of nine of the 35 known species: E. albofasciata Smith, E. analis Lepeletier, E. flava Friese, E. metatarsalis Friese, E. nigrita Friese, E. obscura Friese, E. picta Smith, E. zonata Mocsáry, and E. dejeanii (Camargo et al. 1975; Roubik and Michener 1980; Raw 1992; Laroca et al. 1993; Hiller and Wittmann 1994; Inouye 2000; Thiele and Inouye 2007; Werneck 2012; Gaglianone et al. 2015; Rozen 2016).

E. dejeanii is the only member of the subgenus E. (Anepicharis ) Moure and is widely distributed in Brazil (Moure et al. 2007). Preliminary observations on its bionomy were published by Hiller and Wittmann (1994), but still important data on its life cycle remains unknown. In this study, new information on the nesting habits and life cycle of 
E. dejeanii are presented. These data are complementary with those previously known for this species, increasing the knowledge on the bionomy of this solitary oil-collecting bee.

\section{MATERIAL AND METHODS}

A population of E. dejeanii was studied between November 2017 and January 2018 at Ilha das Flores, Babitonga's Bay, north coast of Santa Catarina state, southern Brazil. The aggregation was located in an uncovered area with sandy and flat soil (Fig. 1). This island contains approximately 9 ha and is formed mainly by arboreal vegetation of dense ombrophilous forest. The climate of the region, according to Köppen (1948) is classified as "Cfa" (warm and humid subtropical) with well-defined seasons and without periods of drought throughout the year.
The nesting habits of the species were directly observed and digitally recorded. To guide the excavations and to obtain the size of tunnels was followed the methodology proposed by Marinho et al. (2018) which consists in to use a flexible rubber tube marked with centimeters. We used a tube with $0.6 \mathrm{~cm}$ of diameter and $150 \mathrm{~cm}$ in length. The brood cells collected were conditioned separately in plastic bags-containing substrate (sand) from the nesting site to accompany the immature development in the laboratory. The nests' architectures were registered, and the cells were dimensioned.

The hours of external activities of females and males were registered, as well as the frequency of types of floral resources collected by females (pollen or oil) throughout the days. Larvae in predefecating and postdefecating stages are morphologically described and illustrated.

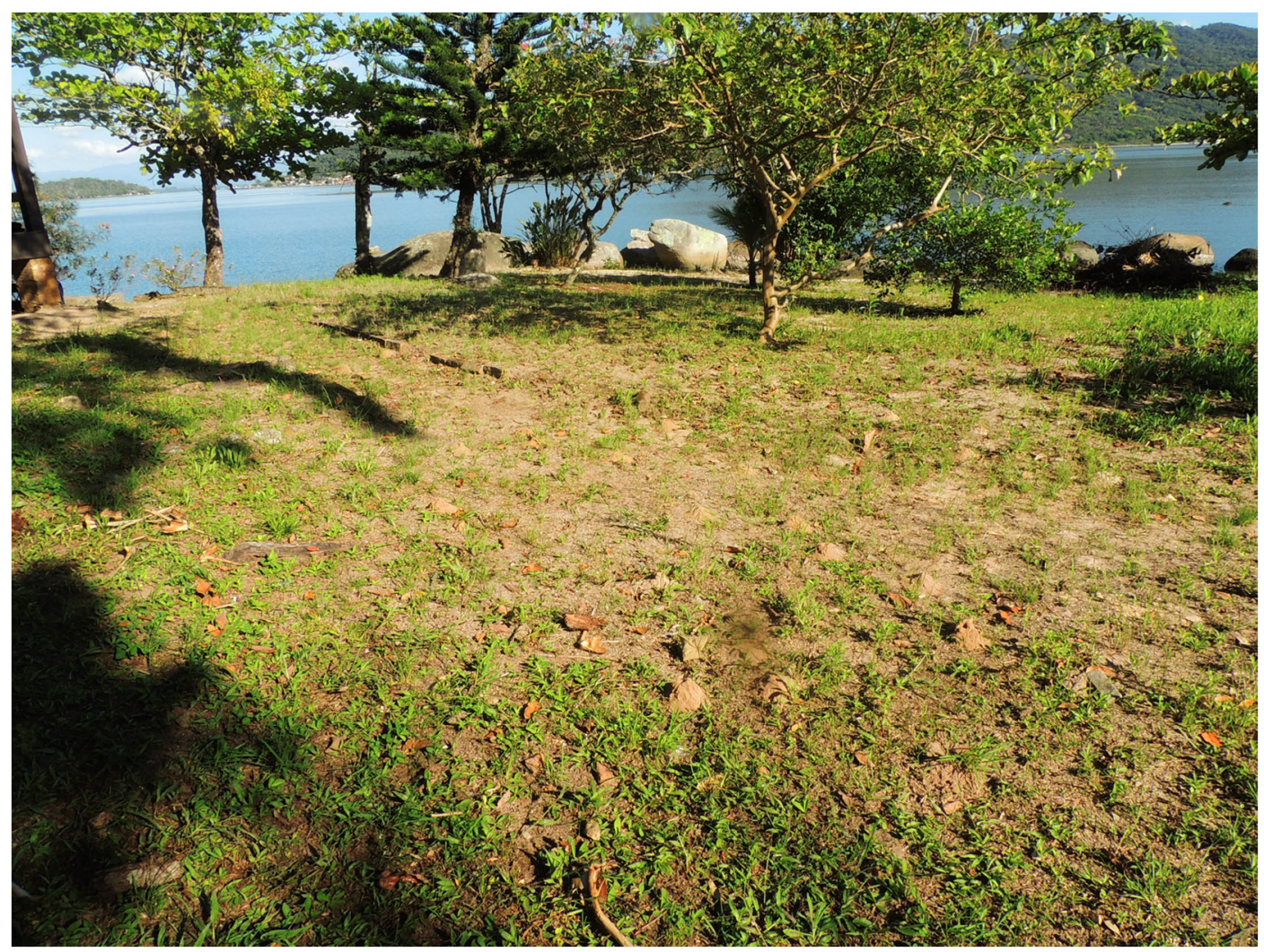

Figure 1. Nesting area of E. dejeanii at Ilha das Flores, Babitonga's Bay, Santa Catarina State, Brazil. 


\section{RESULTS}

\subsection{Sazonality, aggregation, and building new nests}

The nests were aggregated in an area of $120 \mathrm{~m}^{2}$ whose density varied between 1 and $8 / \mathrm{m}^{2}(\bar{X}=$ $3.43 \pm 1.87$ ). More than 100 openings were observed, including new nests and those where occurred only emergencies. The entrances remained always opened. Externally, the newly founded nests $(N=25)$ had a small mound of sand (tumulus) resulting from the excavation, with averages of $5 \mathrm{~cm}$ in height and $11 \mathrm{~cm}$ in diameter. The entrances had a circular format with $1.5 \mathrm{~cm}$ in diameter $(\bar{X}=1.51 \pm 0.6 \mathrm{~cm} ; N=25)$, and almost all were facing upwards. Eventually, some nests had double entrances (Fig. 2a) or had a small lateral slope on the tumulus (Fig. 2b).

Some female's activity was observed in some nests without tumuli, which would indicate that they were reusing some pre-existing nests. The population studied was univoltinous, with only one generation per year. The adult period of the specimens, as well as the nesting activity, lasted approximately 70 days. The immature stages, between egg and pre-pupa, occurred in less than 60 days. The diapause occurred in the postdefecating larval stage.

For the choice of nesting site, females made short zig-zag flights very close to the ground (3$5 \mathrm{~cm}$ height). After landing, the excavation began immediately and the activity was maintained uninterruptedly throughout the day. Females began the excavation with the use of fore and middle legs, with fast movements to push back the sand, under the body. The head was face down, making short movements with the mandibles from front to back. The females pushed the excavated sand sideways, making fast and coordinated movements with the hind legs. The first few centimeters of the tunnel were started downwards, vertically. Short vibrations could be heard during this step.

Once the bee was fully inserted into the tunnel, the female used the distal terga to push the sand outward, from bottom to up. When the metasoma reached the surface, the bee made semicircular movements by spreading the sand on the outer

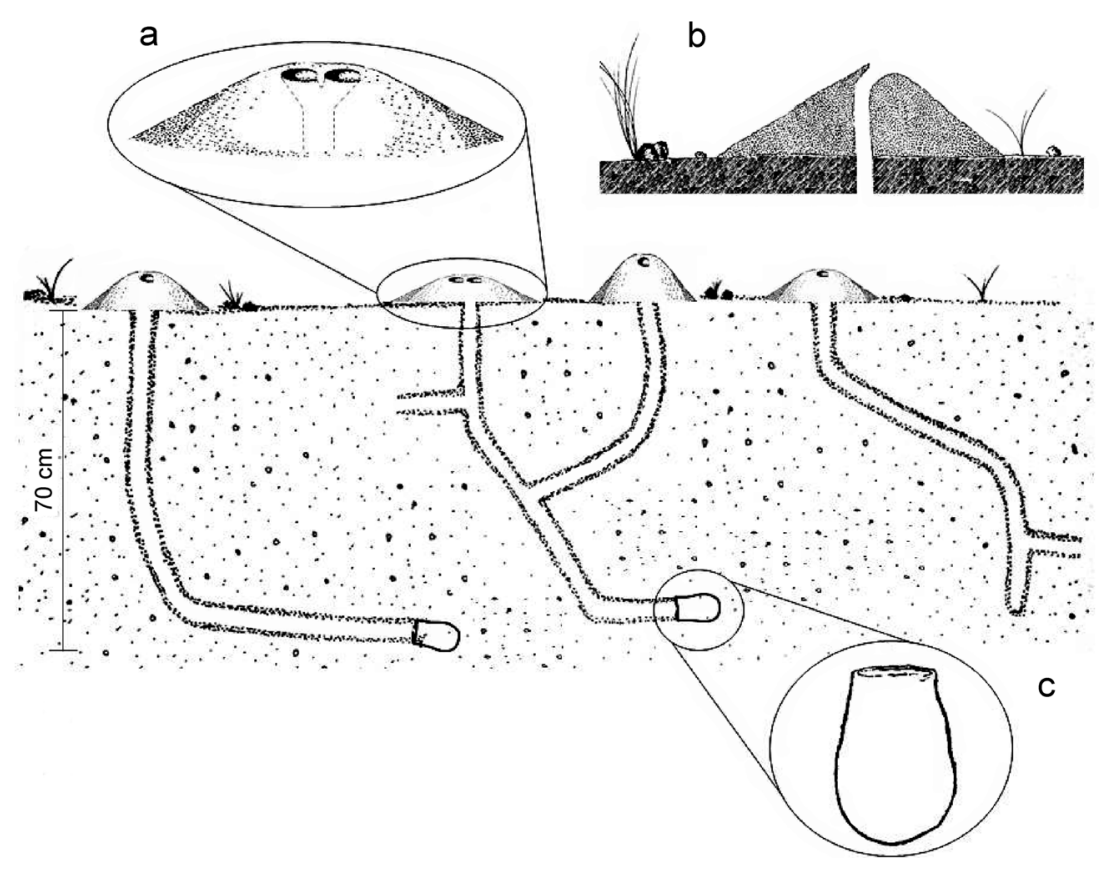

Figure 2. Schematic drawing showing nest architectures found in E. dejeanii, with double entrance (a); small curve in the tumulus (b); location of the brood cells (c). 
side homogeneously forming the tumulus. Newly built nests were observed $(N=15)$, and their depths were registered after 24, 48, 72, and $96 \mathrm{~h}$. However, no depth variations were detected after $24 \mathrm{~h}$.

During the night, the females rested in the nests, and they started to fly daily around 6:30 pm (daylight saving time-DST). In the first day, after emergence and mating, females searched for a place to build their nests and started the excavations. In the second day, the females performed the first flights returning without resources in their scopes. The collection of floral oil started later in the morning and lasted until the late of the afternoon. Eventually, the collection of oils extended until the morning of the next day. Pollen collections began at the third day or the beginning of the fourth day. To collect pollen, the trips lasted from 6 to $31 \mathrm{~min}(\bar{X}=14 \pm 6.6 ; N=$ 25); while to collect oil, the females lasted from 11 to $18 \min (\bar{X}=12 \pm 2.35 ; N=8)$. The females which arrived with pollen + oil in their scopae lasted, on average, $13 \min ( \pm 2.2 ; N=8)$. Inside the nests, the females stayed between 8 and $55 \min (\bar{X}=23 \pm 3.55 ; N=20)$. The complete period between the excavation and the abandonment of the nests occurred in 3 to, rarely, 4 days (Fig. 3 ).

\subsection{Nesting architecture and brood cell}

The nests excavated $(N=15)$ presented heterogeneity in their architecture. Some of them began with a small descending tunnel $(20-30 \mathrm{~cm})$, followed by a slope of $30-45^{\circ}$ from the ground level by a further $20-30 \mathrm{~cm}$, becoming after, horizontal. Others presented a vertical tunnel with more than $30 \mathrm{~cm}$ in depth until slope occurs. In the end, the tunnels became horizontal, eventually curved to the right or to the left. In the inclined route, short branches could be found with or without brood cells. Vertical tunnels with a smallinclined stretches were also found, becoming briefly horizontal at the end. The depths ranged from 40 to $140 \mathrm{~cm}(\bar{X}=77 \mathrm{~cm} \pm 26.14 ; N=25)$. There were found only one or two brood cells per nest, located at the end of the tunnel and/or in short branches (Fig. 2c). The cell position was always horizontally or slightly inclined.

The brood cells size ranged between 35 and $36 \mathrm{~mm}$ in length $(\bar{X}=35.2 \mathrm{~mm} \pm 0.45 ; N=5)$, $19-20 \mathrm{~mm}$ in maximum diameter $(\bar{X}=$

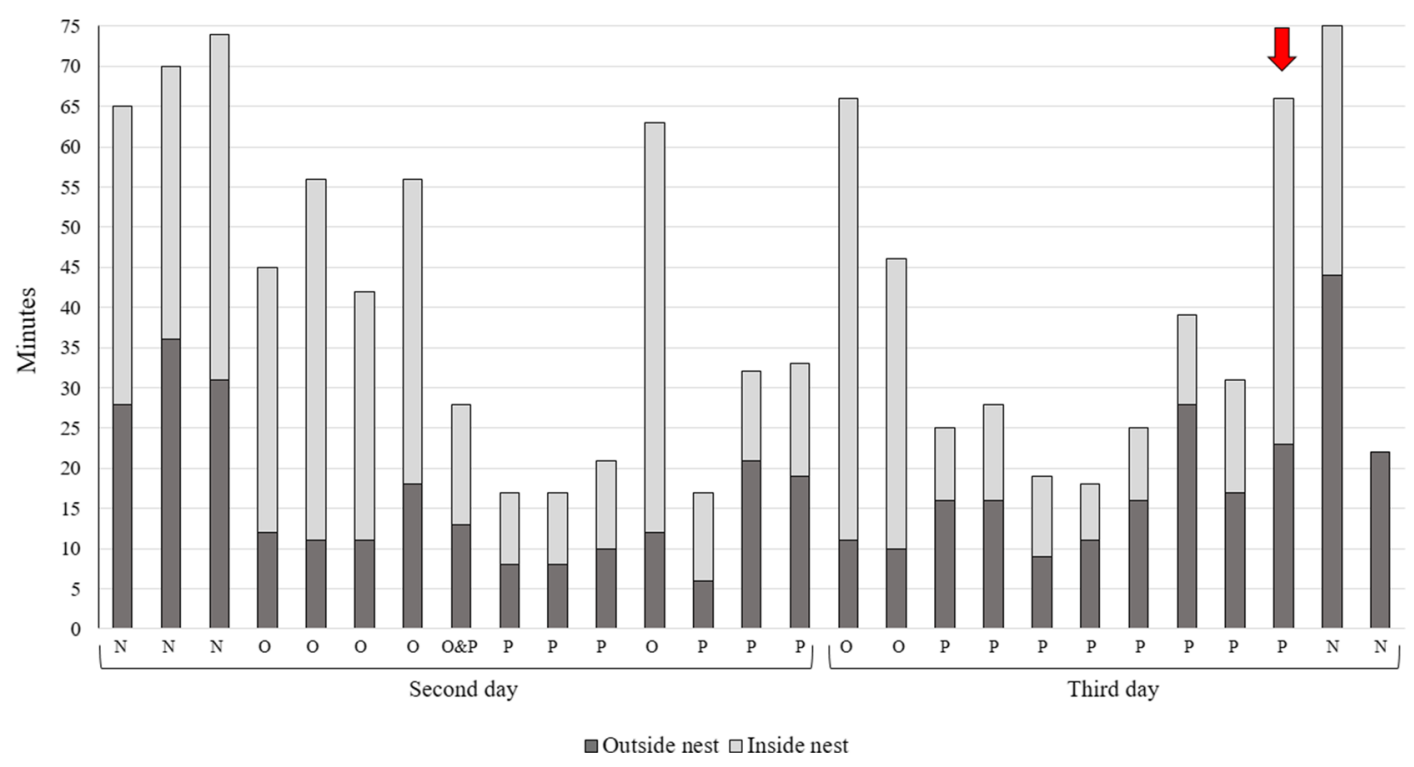

Figure 3. Sequence os flights performed by a female of E. dejeanii during the 2 days that the nest was active. On the first day, the female dug the nest. The red arrow suggests the moment of oviposition. 
$19.6 \mathrm{~mm} \pm 0.55 ; N=5)$ and $10-11 \mathrm{~mm}$ in the operculum diameter $(\bar{X}=10.4 \mathrm{~mm} \pm 0.55 ; N=$ $5)$. The volume of the cells had, on average, $3.8 \mathrm{~mL}( \pm 0.04 ; N=5)$. Inside, a food composed with a whitish, dry, and compressed mass of pollen was found occupying approximately $30 \%$ of the cell. The inner wall of the cell was finely coated by a polished, bright slightly streaking layer. The operculum is flat, retracted into the edge of the cell, and completely sealed. Its inner wall does not have a polished and glossy layer. However, the sand is strongly compacted, since it seems that some substance has been added to stick the grains. The total wall thickness of the cell is approximately $1 \mathrm{~mm}$, twice the thickness of the operculum. No cocoons were observed inside the cells that contained pre-pupa stage.

In one nest, a brood cell was found with a quite brittle dead adult covered by several collembolans of the genus Folsomia Willem
(Isotomidae: Proisotominae). Three specimens of Tetracha brasiliensis (Kirky) (Coleoptera: Cicindelidae) were found in different nests during the excavations, however, were not inside the cells. This is the first record of this species interacting with nests of Epicharis bees.

\subsection{Immature stages}

Five cells were laterally opened to observe the activity of the immatures (Fig. 4e). The larva intercalates periods of feeding and resting during several times a day until the pollen mass ends at around 25-30 days. During this period, its size changes from approximately 5 to $22 \mathrm{~mm}$ when it reaches the stage of postdefecating larva. Throughout the feeding period, the larva maintains a whitish coloration and a turgid appearance. In the postdefecating stage, the larva becomes yellowish and more flaccid.
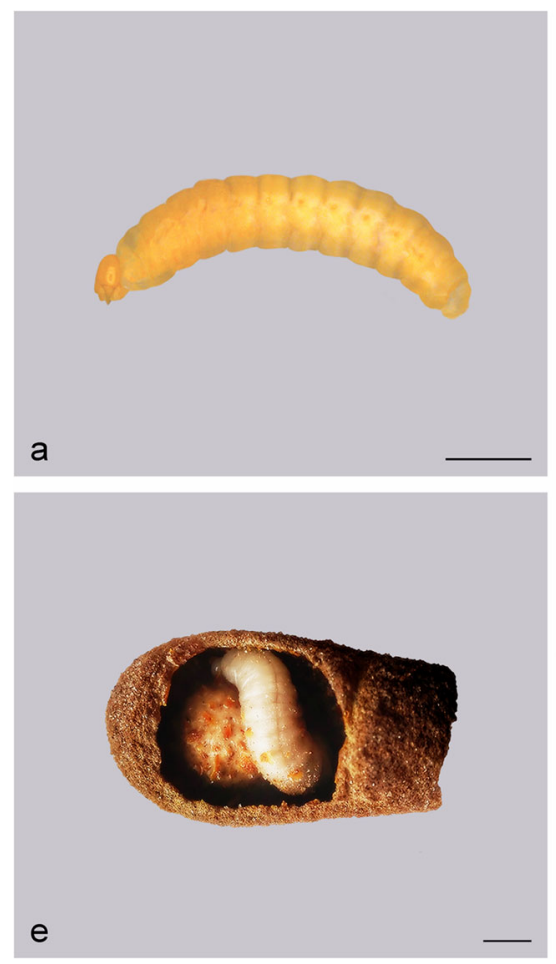
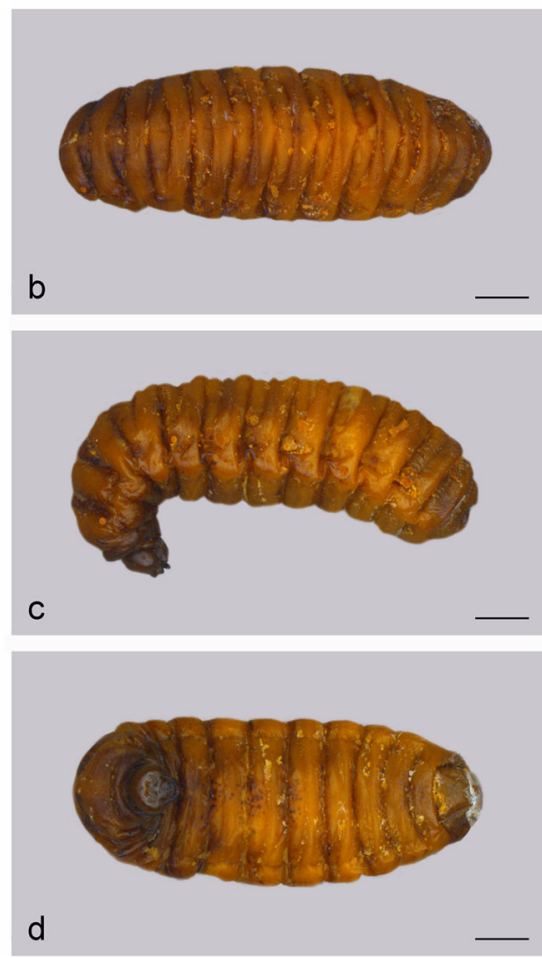

Figure 4. Predefecting larva of $E$. dejeanii (lateral view) (a); postdefecating larva of E. dejeanii: lateral view (b ), dorsal view (c), ventral view (d); Larva feeding in brood cell (e). Scales $\mathrm{a}-\mathrm{d}=3 \mathrm{~mm}$; e $=5 \mathrm{~mm}$. 


\subsubsection{Predefecating larva (Figure 4a)}

The larva's body has whitish/light yellow coloration, length of $12 \mathrm{~mm}$, and diameter of $2 \mathrm{~mm}$. It also has glabrous, thin, and slightly sclerotized integument. Ten pairs of brown spiracles measure equally $0.13 \mathrm{~mm}$ of diameter, with their edges spare and more sclerotized than the body. The first two pairs positioned near the posterior edge of the thoracic segments I-II, absent in segment III; the other pairs are positioned near the anterior edge of the abdominal segments I-VIII. The anal opening is not visible. The cephalic capsule is rounded, with similar coloration than the rest of the body, $1.4 \mathrm{~mm}$ width and $1.25 \mathrm{~mm}$ )in length (from vertex to labrum). The clypeus and labrum are distinguished by a subtle suture. The mandible is welldeveloped, with $0.6 \mathrm{~mm}$ in length, directed anteroventrally; its base measures $2 / 3$ of its total length. The mandibular integument has darkened band and serrated margin and apical tooth present. The maxilla is well-developed with maxillary palpus absent/not visible. The antennae are absent; the antennal alveolus is weakly developed. The longitudinal sulcus is not well-defined, from the supraclypeal area to the apex.

\subsubsection{Postdefecating larva (Figure $4 b-d$ )}

The larva's body has dark yellow integument, lighter and less sclerotized than the cephalic capsule, length of $22 \mathrm{~mm}$, and diameter of $9 \mathrm{~mm}$. Ten pairs of dark brown spiracles are more sclerotized and spare (diameter $0.28 \mathrm{~mm}$ ). The first two pairs are positioned near the posterior edge of the thoracic segments I-II, absent in segment III; the others are positioned near the anterior edge of the abdominal segments I-VIII, as in predefecating stages. The peritreme is weakly developed; below it, there are several white short bristles directed towards the opening at the center of the spiracle. The anal opening's transversal length is $1.2 \mathrm{~mm}$. The ventral surface of the body has no tubercles or other projections; the dorsal surface has two distinct bands of spicules ( $0.08 \mathrm{~mm}$ in length) in the II-III thoracic segments, and the I-VI abdominal segments are separated by a medial region. The thoracic and abdominal segments have 4-11 spicules on each band. The number of spicules per band varies between the right and left sides. Dorsal and ventral surfaces of the body are weakly transversely striated.

The cephalic capsule is round, dark yellow, more sclerotized than the rest of the body, $2.0 \mathrm{~mm}$ of width and length (from vertex to the labrum). The epistomal sulcus is unformed. The clypeus and labrum are light brown, striated, and distinctly separated by a strong sulcus; labrum bilobed. The supraclypeal area has two depressions located in the frontal region. The mandibles are directed anteroventrally and are darker than the cephalic capsule, with rounded anterior margin, not serrated and without apical tooth (mandibular length $1.3 \mathrm{~mm}$ ). The maxilla is cylindrical with maxillary palpus slightly evident. Prementum and postmentum are separated by a suture. Antennal alveolus is weakly evident. Antenna is absent. Salivary opening is located transversally to the front of the labiomaxillary region.

\section{DISCUSSION}

The only information available on some bionomical aspects of $E$. dejeanii was published by Hiller and Wittmann (1994) who studied a population in Rio Grande do Sul state, Brazil. Although this study also occurred in the southern region of that country, some behavioral variations were observed among both populations, such as periods of activity, density of aggregations, number of cells per nest, and depths.

The southern region of Brazil has a subtropical climate, with winters well marked by low temperatures. Due to this, in several solitary bees, during the mild seasons (autumn and winter), adults are not present, and the immatures are in diapause (Michener 2007). In this period, there is a reduction of metabolic activity (Belozerov 2009), a strategy that allows the individuals to remain safe until the return of favorable climatic conditions for their complete development (Danks 2007; Michener 2007).

The period of adult activities was longer in the present study, and the emergence at Ilha das Flores began 1 month earlier than that observed by Hiller and Wittmann (1994). The begin of the diary 
activities was later in Ilha das Flores, since those authors observed the first flights of the day at 5:30 am, therefore, an hour earlier.

The construction of the main tunnel occurred before the first $24 \mathrm{~h}$, corroborating the observations of Hiller and Wittmann (1994) that affirmed to be $18 \mathrm{~h}$ the necessary time to finish it. However, the authors suggested that the construction of the first brood cell should also be included at this time. In this study, the females were only observed returning with floral oil from the second day after nest establishment, therefore, the cell should be started only from this moment. Some females reused preexisting nests, and this behavior was also observed in E. nigrita by Martins et al. (2019). These authors registered females that excavated their nests behaving very similarly to $E$. dejeanii .

The greater daily energy investment in the population studied by Hiller and Wittmann (1994) may be one reason why the aggregation of adults had a period of approximately 30 days less than in Ilha das Flores. Other factors may be linked to the availability of the necessary floral resources as well as the temperature, besides the locality has a temperate climate and summer with lower temperatures.

The sandy and uncompacted soil facilitates the excavations, which may justify the great depth found in some nests. Tunnels containing more than $1 \mathrm{~m}$ in length were recorded only in E. flava (Camargo et al. 1975), E. metatarsalis (Inouye 2000; Thiele and Inouye 2007) and E. picta (Werneck 2012). However, none of them reached the maximum depth found in the present study.

The shallowest tunnel found at Ilha das Flores was $40 \mathrm{~cm}$, while Hiller and Wittmann (1994) recorded nests from $25 \mathrm{~cm}$. Significant differences are in the density of aggregation and in the high number of brood cells that the same authors found, reaching 25 entrances $/ \mathrm{m}^{2}$ and 52 brood cells in five excavated nests (average of 10 brood cells per nest). These numbers are much higher than those found in the present study (maximum of 8 entrances $/ \mathrm{m}^{2}, 1$ or 2 cells per nest).

The plasticity in the quantity of brood cells was already observed in Centris flavifrons (Fabricius) (Martins et al. 2014) and in E. nigrita (Martins et al. 2019), whose variation was between 1 and 12 and 1-5 cells per nest, respectively. The same authors discussed this plasticity when compared the data presented by other studies (see Vinson and Frankie 1988; Vinson et al. 1996, 1997; Gaglianone 2005; Rêgo et al. 2006; Gonzalez et al. 2007). This could be the reason to explain the high difference between our data and those presented by Hiller and Wittmann (1994).

Nesting on sandy substrates, as well as low numbers of the brood cells, are characteristics of the Epicharis species studied (Roubik and Michener 1980; Coville et al. 1983; Raw 1992; Gaglianone 2001, 2002; Rocha-Filho et al. 2008; Gaglianone et al. 2015). Thus, when contrasted with the data presented by Hiller and Wittmann (1994), the number of the brood cells in each nest is very low. However, it is in conformity with the information known for the genus, since other studies showed, for the most part, one or two cells per nest excavated, except those found by Rozen (2016) for E. albofasciata and Martins et al. (2019) for E. nigrita .

Hiller and Wittmann (1994) also found brood cells in an irregular arrangement, ranging from horizontal to vertical and with different angulations, always close to each other. In the present study, the cells found were arranged horizontally or slightly inclined in relation to the horizontal level. In E. zonata, the cells found were almost always vertical, in ramifications that isolated one cell from the other, and the nests did not present great depths $(15-52 \mathrm{~cm})$ (Roubik and Michener 1980). Rozen (2016) also verified that the positioning of the E. albofasciata cells is vertical, and the density varied between 2 and 7 per nest, adhered one to each other; the depth of the tunnels also being shallow $(16-30 \mathrm{~cm})$. Rocha-Filho et al. (2008) studying nests of E. bicolor Smith, 1854, verified that the nests of that species had short extensions $(10-25 \mathrm{~cm})$ and vertical architectures varying between one and two cells per nest. The arrangement of the cells found by those authors varied between horizontal, transversal, and vertical. Considering this, both the arrangement of the cells and the depths of nests do not seem to have a pattern within the genus.

The brood cells found in the excavations were taken to the laboratory and opened to monitor the development of the immatures. However, they were attacked by fungi. Problems related to fungi have also been reported by Gaglianone (2001), 
Werneck (2012), Martins et al. (2014) and Gaglianone et al. (2015). Gaglianone (2001) reported the difficulty in keeping the cells in the laboratory without suffering fungi attacks. This author also noted fungi attack in cells of Centris scopipes Friese at its nesting site.

According to our results, postdefecating larvae do not form a cocoon, as already mentioned by Hiller and Wittmann (1994). The absence of cocoon was also observed in all other species of Epicharis (Rozen 1965; Roubik and Michener 1980; Gaglianone 2005; Gaglianone et al. 2015). The development between egg and pre-pupa stages occurred in less than 2 months in the present study. This rapid growth of immatures was also reported by Roubik and Michener (1980), Rocha-Filho et al. (2008) and Gaglianone et al. (2015) in other species of the genus.

Reports of cleptoparasitism in Centridini by bees of the genus Mesoplia Lepeletier (Apidae: Ericrocidini) and Rhathymus Lepeletier and Serville (Apidae: Rhathymini), as well as beetles of the family Meloidae, especially those of the genus Tetraonyx Latreille (Coleoptera: Meloidae), are abundant in the literature (see Camargo et al. 1975; Raw 1992; Hiller and Wittmann 1994; Morato et al. 1999; Gaglianone 2001, 2005; Rozen 2003; Rocha-Filho et al. 2008). Adults of the cicindelid beetle T. brasiliensis (Coleoptera: Cicindelidae) were found inside three nests. The presence of specimens of this species and family associated with Epicharis nests is here recorded for the first time. However, in the months of March and April, very close to the site of the aggregation of $E$. dejeanii were observed some nests containing cicindelid larvae. Therefore, it is possible that the T. brasiliensis adults found in nests were only looking for oviposition cavities, although they are voracious predators of invertebrates (Pearson and Vogler 2001). Interactions involving cleptoparasitism or predatism are not known for this genus of beetle and Centridini bees.

New data on the nesting habits of E. dejeanii are presented here, among them the nest architecture, the deepest nests so far found in Centridini, as well as information on the morphology of immatures. Other information corroborates characteristics such as a well-defined seasonality, short time of activity of adults, and long period of development of the immatures, diapause in the pre-pupa stage in subtropical or temperate regions, as well as univoltism, reinforcing to attributes present in the genus Epicharis .

\section{ACKNOWLEDGMENTS}

We thank the Coordenação de Aperfeiçoamento de Pessoal de Nível Superior (CAPES) for providing a $\mathrm{PhD}$ scholarship to the former author; to Mr. Nei Osvaldo Silva and Mr. Nivaldo Jose da Silva for allowing us the access to the area studied; the island resident Mr. Paulo Kolombesky and his wife Mrs. Marli T. Kolombesky for the information provided. We also thank Vanessa Feretti by the preliminary information about these bees. This paper is part of the SIGMA project No. $21565 \mathrm{MN} / \mathrm{UFRJ}$ and the contribution number 33 from the HYMN.

\section{AUTHOR'S CONTRIBUTIONS}

Both the authors participated in the interpretation of the data; E.Dec wrote the paper and F. Vivallo participated in the revisions of it. All authors read and approved the final manuscript.

\section{COMPLIANCE WITH ETHICAL STANDARDS}

Conflict of interest The authors declare that they have no conflict of interest.

Biologie de nidification et stades immatures de l'abeille collectrice d'huile Epicharis dejeanii (Apidae: Centridini)

abeille solitaire / développement larvaire / architecture de nidification / Baía da Babitonga

Nestbiologie und präimaginale Entwicklungsstadien der Öl-sammelnden Biene Epicharis dejeanii (Apidae: Centridini)

Solitärbienen / Larvenentwicklung/ Nestarchitektur/ Baía da Babitonga 


\section{REFERENCES}

Belozerov V.N. (2009) New aspects in investigations of diapause and non-diapause dormancy types in insects and other arthropods. Entomol Rev 89, 127-136.

Buchmann S.L. (1987) The ecology of oil flowers and their bees. Annu Rev Ecol Syst 18, 343-369.

Camargo J.M.F., Zucchi R., Sakagami S.F. (1975) Observations on the bionomics of Epicharis (Epicharana) rustica flava (O1.) including notes on its parasite Rhathymus sp. (Hym., Apoidea: Anthophoridae). Studia Ent 18(1-4), 313-339.

Coville R.E., Frankie G.W., Vinson, S.B. (1983) Nests of Centris segregata (Hymenoptera: Anthophoridae) with a review of the nesting habitats of the genus. $J$ Kansas Entomol Soc 56, 109-122.

Danks H.V. (2007) The elements of seasonal adaptations in insects. Can Entomol 139(1), 1-44.

Gaglianone M.C. (2001) Nidificação e forrageamento de Centris (Ptilotopus) scopipes Friese (Hymenoptera, Apidae). Rev Bras Zool 18, 107-117.

Gaglianone M.C. (2002) Uma análise comparativa da nidificação de espécies de Epicharis, in: Garófalo C.A. (Ed.), Anais do V Encontro sobre Abelhas, Ribeirão Preto, Facul. Fil. Ciênc. e Letras de Ribeirão Preto, pp. 47-52.

Gaglianone M.C. (2005) Nesting biology, seasonality, and flower hosts of Epicharis nigrita (Friese, 1900) (Hymenoptera: Apidae: Centridini), with a comparative analysis for the genus. Stud Neotrop Fauna Environm 40(3), 191-200.

Gaglianone M.C., Werneck H.A., Campos L.A.O (2015) Univoltine life cycle of two species of Epicharis Klug, 1807 (Apidae, Centridini) and notes on its cleptoparasites Tetraonyx spp. (Coleoptera, Meloidae), in: Aguiar A.J.C., Gonçalves R.B., Ramos K.S. (Eds.), Ensaios sobre as abelhas da Região Neotropical: homenagem aos 80 anos de Danuncia Urban. $1^{\text {st }}$ Edition, Curitiba: UFPR, 397-410.

Gonzalez V.H., Ospina M., Palacios E., Trujillo E. (2007) Nesting habitats and rates of cell parasitism in some bee species of the genera Ancyloscelis, Centris and Euglossa (Hymenoptera, Apidae) from Colombia. Bol Mus Entomol Univ del Valle 8(2), 23-29.

Hiller B., Wittmann, D. (1994) Seasonality, nesting biology and mating behaviour of the oil-collecting bee Epicharis dejeanii (Anthophoridae, Centridini). Biociências 2, 107-124.

Inouye B.D. (2000) Use of visual and olfactory cues for individual nest hole recognition by the solitary bee Epicharis metatarsalis (Apidae, Anthophorinae). J Insect Behav 13(2), 231-238.

Köppen W. (1948) Climatología: con un estudio de los climas de la tierra. México: Fondo de Cultura Económica.
Laroca S., Reynaud dos Santos D.T., Schwartz Filho D.L. (1993) Observations on the nesting biology of three Brazilian centridini bees: Melanocentris dorsata (Lepeletier 1841), Ptilotopus sponsa (Smith 1854) and Epicharitides obscura (Friese 1899) (Hymenoptera Anthophoridae). Trop Zool 6, 151-163.

Marinho D., Andrade J., Araujo R.O., Vivallo F. (2018) A new technique in the excavation of ground-nest bee burrows (Hymenoptera: Apoidea). Rev Bras Entomol $62,1-4$.

Martins C.F., Peixoto M.P., Aguiar C.M.L. (2014) Plastic nesting behavior of Centris (Centris) flavifrons (Hymenoptera: Apidae: Centridini) in an urban area. Apidologie 45(2), 156-171.

Martins, C.F., Neto, V.I.S., Cruz, R.D.M. (2019) Nesting biology and mating behavior of the solitary bee Epicharis nigrita (Apoidea: Centridini). J Apic Res 1-11.

Michener C.D. (2007) The Bees of the World, $2^{\text {nd }}$ ed. Baltimore: John Hopkins University Press.

Morato E., Garcia M.V.B., Campos L.A.O. (1999) Biologia de Centris Fabricius (Hymenoptera, Anthophoridae, Centridini) em matas contínuas e fragmentos na Amazônia Central. Revta Bras Zool 16, 1213-1222.

Moure, J.S., Melo, G.A.R., Vivallo, F. (2007) Centridini Cockerell \& Cockerell. In: Moure, J.S., Urban, D. \& Melo, G.A.R. (Orgs), Catalogue of bees (Hymenoptera, Apoidea) in the Neotropical Region. Sociedade Brasileira de Entomologia, Curitiba, Brazil, pp. 83-142.

Neff J.L., Simpson B.B. (1981) Oil-collecting structures in the Anthophoridae (Hymenoptera): morphology, function and use in systematics. J Kansas Entomol Soc 54, 95-123.

Pearson, D.L., Vogler, A.P. 2001. Tiger beetles: the evolution, ecology and diversity of the Cicindelids. Cornell University Press, Ithaca, New York. 333 p.

Raw A. (1992) Mate searching, population size and nest site requirements of two univoltine solitary bees of genus Epicharis (Hymenoptera, Anthophoridae) in Brazil. Entomologist 111, 1-9.

Rêgo M.C.M., Albuquerque P.M.C., Ramos M.C., Carreira L.M. (2006) Aspectos da biologia de nidificação de Centris flavifrons (Friese) (Hymenoptera: Apidae, Centridini), um dos principais polinizadores do murici (Byrsonima crassifolia L. Kunth, Malpighiaceae), no Maranhão. Neotrop Entomol 35(5), 579-587.

Rocha-Filho L.C., Silva C.I., Gaglianone M.C., Augusto S.C. (2008) Nesting behavior and natural enemies of Epicharis (Epicharis) bicolor Smith 1854 (Hymenoptera Apidae). Trop Zool 21, 227-242.

Roubik D.W., Michener C.D. (1980) The seasonal cycle and nests of Epicharis zonata, a bee whose cells are below the wet-season water table (Hymenoptera, Anthophoridae). Biotropica 12, 56-60.

Rozen J.G. (1965) The larvae of the Anthophoridae (Hymenoptera, Apoidea). Part 1. Introduction, Eucerini, and Centridini (Anthophorinae). Am Mus Novit 2233, 1-27. 
Rozen J.G. (2003) Eggs, ovariole numbers, and modes of parasitism of cleptoparasitic bees, with emphasis on neotropical species (Hymenoptera: Apoidea). Am Mus Novit 3413, 1-36.

Rozen J.G.J. (2016) Nesting biology of the solitary bee Epicharis albofasciata (Apoidea: Apidae: Centridini). Am Mus Novit 3869, 1-8.

Thiele R., Inouye B.D. (2007) Nesting biology, seasonality, and mating behavior of Epicharis metatarsalis (Hymenoptera: Apidae) in Northeastern Costa Rica. Ann Entomol Soc Am 100, 596-602.

Vinson S.B., Frankie G.W. (1988) A comparative study of the ground nests of Centris flavifrons and Centris aethiocesta Hymenoptera: Anthophoridae). Entomol Exp Appl 49, 181-187.

Vinson S.B., Frankie G.W., Williams H.J. (1996) Chemical ecology of the genus Centris (Hymenoptera: Apidae). Fla Entomol 79, 109-129.
Vinson S.B., Williams H.J., Frankie G.W., Shrum G. (1997) Floral lipid chemistry of Byrsonima crasssifolia (Malpighiaceae) and a use of floral lipids by Centris bees (Hymenoptera: Apidae) Biotropica 29, 76-83.

Vogel S. (1976) Lysimachia: Olblumen der Holarktis. Naturwissenschaften, 63, 44-45p.

Werneck H.A. (2012) Biologia de nidificação, sazonalidade e inimigos naturais de Epicharis (Epicharoides ) picta (Smith, 1874) (Apidae: Centridini) no município de Viçosa, MG-Brasil. Federal University of Viçosa, Minas Gerais.

Publisher's note Springer Nature remains neutral with regard to jurisdictional claims in published maps and institutional affiliations. 